A. G. MYATT

\title{
Promoting the Use of Literature at Boston Spa
}

\begin{abstract}
The British Library Lending Division is the only national library specifically devoted to interlending and receives an average of nearly 11,000 requests every working day, of which over 15 percent are from overseas. In addition, the library is actively concerned with promoting the use of published information and has education, translating, and publications programs to help achieve this end. The development of these programs is briefly described, and current Lending Division publications are listed. Courses, translating services, and publications assist the library's users at home and abroad and contribute to bibliographic access, to the professional literature, and to the general dissemination of knowledge.
\end{abstract}

$\mathrm{T}$ HE ACTIVITIES of the British Library Lending Division as a centralized loan and photocopy service are well known. ${ }^{1-3}$

Currently it is handling three quarters of all interlibrary loan requests originating in Great Britain, nearly 84 percent of which are satisfied from its own holdings. It is the only national library specifically dedicated to interlending and receives an average of nearly 11,000 requests every working day, of which over 15 percent are from overseas.

However, the Lending Division, in addition to collecting material as comprehensively as possible and making it available through a worldwide network of centers, has a number of other functions that are more or less closely related to interlending, but which are probably less familiar. These functions are mainly concerned with promoting the use of published information. To help achieve this the library conducts three major

A. G. Myatt is head of external relations and services, British Library Lending Division, Boston Spa. programs: in education, translating, and publishing.

\section{Courses and Seminars}

In the early 1960s it became clear that academic libraries in the United Kingdom, while many of them gave orientation talks to new students, were making little effort to assist their clients in the effective use of literature-a task that was becoming more urgent as both the volume of literature and the complexity of secondary services developed.

Since the National Lending Library for Science and Technology, as it was then, had a very large stock of literature, it seemed important to maximize the use of this and, at the same time, to provide some assistance to academic libraries. A program of courses was therefore developed, aimed principally at academic library staff and research workers to familiarize them with the problem of using the literature and also provide them with a possible model for courses that could be run in their own institutions.

In the last ten years more than 1,500 
people have attended courses and seminars at Boston Spa. The majority have been "use of literature" courses in science, technology, and the social sciences and have been attended by library staff and academic staff working within higher or continuing education.

Typically, a course lasts for about a week and includes lectures on subjects such as secondary services, reports, dissertations, foreign literature, and translations. The main emphasis in all courses is on practical work, to which at least half of the total time of each course is given. Some stress is placed on the importance of the published guides to the literature available at Boston Spa, the most important of which are housed in the Lending Division's public reading room.

Experience suggests that those who attended the courses fell into three main categories with rather different motivations. They were either library staff seeking general additional training, librarians seeking training specifically in the use of scientific literature, or research workers with a need to use the literature.

In latter years the second group was rather smaller, probably because more library staff were entering the United Kingdom profession with a scientific background. Since the creation of the British Library a good deal of thought has been given to the future of short course provision in the British Library as a whole. As far as the Lending Division is concerned, it was decided that the courses should reflect the broadening scope of the Lending Division and, in conjunction with York University Library, courses are now also offered on the use of the literature of the humanities.

The Lending Division's courses have contributed greatly to the development of similar and related courses in academic libraries from the 1960s, an influence that has been widely acknowledged. ${ }^{4,5}$

Few British academic librarians involved in library and information instruction have not attended at least one course at Boston Spa, benefiting not only from the course itself but from exposure to a very wide range of secondary services and other bibliographic tools. At the same time, the courses have been an invaluable means of contact be-

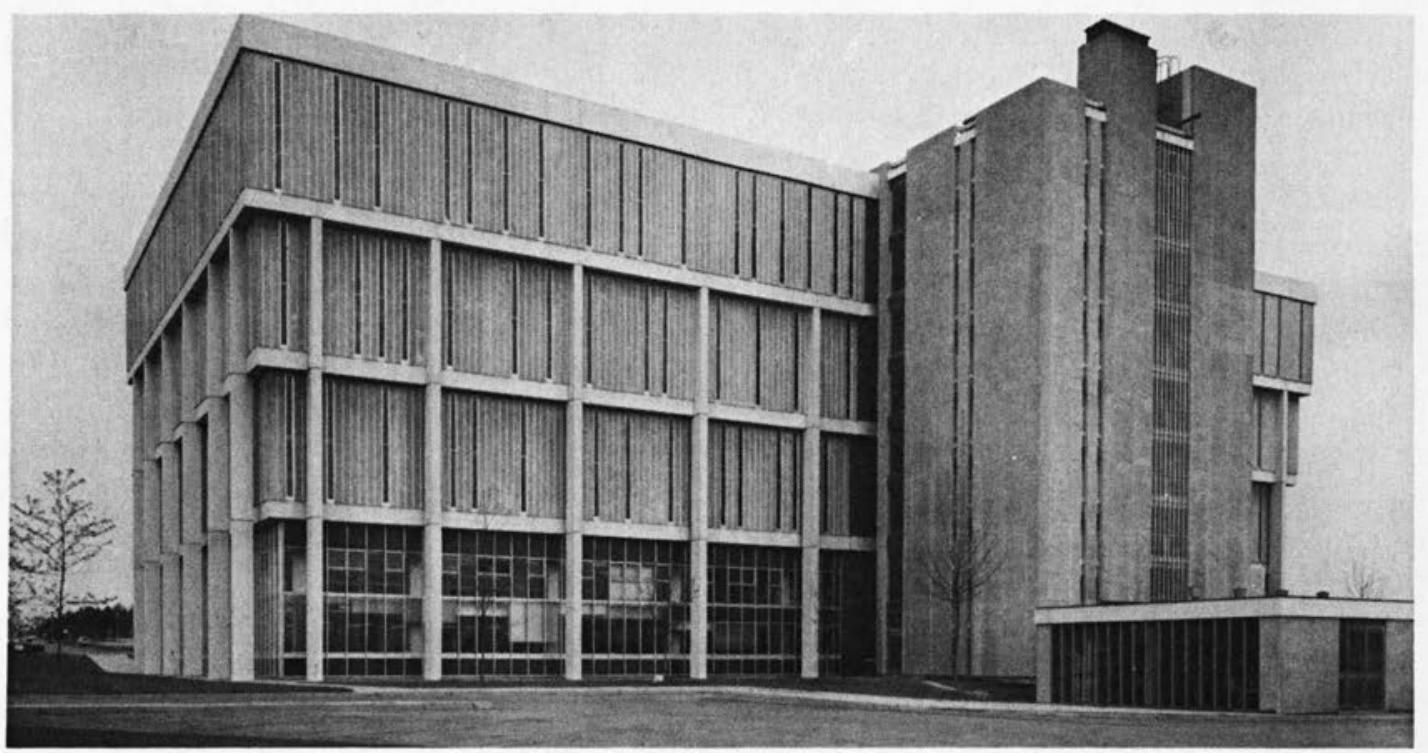

The British Library Lending Division, Boston Spa. 
tween the Lending Division and its users.

\section{Translating}

This activity has been developed from the government-sponsored translation program previously organized by the National Lending Library for Science and Technology. The program covers the translation of whole journals as well as individual articles and books. Its two main aims are clearly related to the main function of the library: to improve access of researchers to literature in foreign languages, especially Russian and Japanese; and to build up the division's stock of literature in English to meet the demands of users who cannot read the original.

\section{Translated Journals}

The Lending Division sponsors the publication of eleven journals consisting entirely of translations (see Appendix 1). The translation, editing, printing, and distribution of each journal are carried out on the Lending Division's behalf by learned societies, research associations, and commercial publishers.

The majority are cover-to-cover translations of single Russian journals; some are selective in that ephemeral or nonscientific articles are omitted; and two contain articles from more than one journal. The first of these, Steel in the USSR, is based on articles appearing in two Russian metallurgical journals; and the second, International Polymer Science and Technology, contains papers from a number of Russian, East European, and Japanese science journals. The latter is perhaps better regarded as a translation service in its own right, since subscribers are given the opportunity to participate in the processes of selection.

\section{Ad Hoc Article Translating}

Since the early 1960s the National Lending Library for Science and Tech- nology, and later the British Library Lending Division, has provided a translating service for articles for United Kingdom users. The service was initially concerned with science and technology but now covers all subjects. The scheme was originally restricted to the translation of articles from Russian but was extended in 1968 to other Cyrillic languages and Japanese, to other Slavonic languages in 1969, to German in 1974, and to all languages in 1976.

All articles are sent to professional translators, since only in this way can the wide range of subject and language expertise required be obtained. The conditions under which translations can be supplied under this service have remained unchanged:

1. If possible, an English abstract or summary should have been checked to ensure that the translation is really needed. Where such a summary has not been consulted, the library will endeavor to provide one.

2. The article must not be from a journal scheduled for translation from cover to cover.

3. The translation must be edited by the requester.

4. The translation must be for private use and not for publication.

Charges were introduced at the end of 1974 , the aim being to recover the expenditure on translators' fees but not overheads, staff costs, accommodation, or materials. The person requesting the translation was charged an amount calculated to produce 40 percent of the fee, the remaining 60 percent being recouped from subsequent sales on the basis that there are an average of three subsequent requests for each translation.

Predictably, there was a reduction in demand for the service as a result of the imposition of charges, but recently, demand has begun to increase and 
around 700 requests are expected in 1977. Most of the current demand is now from industry, mainly in the applied sciences and increasingly from Western European languages. The greatest single advantage to the user as a result of this service is that extensive checking is done for each request.

Only when it is clear that no translation exists or will be made as a result of a cover-to-cover translation program is a new translation made. However, although requesters pay toward the cost of the translation, this does not give them the sole rights over its use. The Lending Division takes active steps to publicize translations and to sell them to other interested parties who may be in direct competition with the initial requester.

\section{Book Translations}

The Lending Division is also prepared to organize and publish the translation of books if a requester in the United Kingdom can demonstrate that there is no English language equivalent to the book in question and that the translation will fill a definite gap in Western knowledge. As with the article translation scheme, the requester is expected to edit the translation and make a contribution toward the cost of having it produced.

Currently about five book translations are produced in this way every year. They are announced in the British $\mathrm{Na}$ tional Bibliography and are available for purchase from the Lending Division. The library has, to date, published translations of more than 130 books in a variety of fields. Some have been produced in conjunction with commercial publishers; others have been produced by the Lending Division on the advice of an individual who is an expert in the field. No special restriction is applied to the Lending Division service, but in practice most requests are in science and technology.
Although the Lending Division has publicized the book translating program, comparatively few orders are received for most of the translations. Although some titles are subsequently sold in large numbers, it is difficult to predict at the stage of an initial request which will prove to be "popular." It is not easy to predict which titles are likely to fill gaps in Western knowledge, as a considerable time lag exists between the publication of a Russian original, for example, and a request for a translation. By the time the translated version is requested, the Russian version may have been publicly available in the West for several years.

The Lending Division regularly receives requests from abroad to have article or book translations made through this program. Although the translating service is restricted to requesters in the United Kingdom at the present time, it is possible that this restriction might eventually be removed.

\section{The Collection of Translations at Boston Spa}

Both the National Lending Library for Science and Technology and the National Central Library collected published translations into English; and the Lending Division now acquires translations of monographs, individual articles, and complete journals in all subject fields. The combined collection now numbers more than 400,000 individual items, together with all issues of more than 250 translated journals.

The principal sources of translations are the National Translations Center in the United States, with which the Lending Division has an exchange agreement; the National Technical Information Service, which supplies many U.S. government-sponsored translations; and firms, universities, government departments, and commercial publishers. The annual intake from these sources is more than 20,000 translations. The 
Lending Division's own translation program results in a further 700 being added to the collection each year. The majority of translations are acquired in "semipublished" form. Most of those from the United States are received in microform, while the majority of the remainder are held as duplicated typescripts.

All the translations received in the Lending Division are indexed under the foreign journal title or, in the case of books, under author and translated title. The Lending Division is prepared to accept inquiries regarding the availability of translations of foreign language articles and books from individuals and organizations, both in the United Kingdom and abroad. About 30,000 inquiries are dealt with annually. If a translation cannot be located at the Lending Division, a check may be made with Aslib's translation index.

\section{Publications and Publishing}

The British Library Lending Division is both a publisher and distributor of a number of publications. Perhaps the most interesting of the division's publications is its Keyword Index of Conferences. The index, which now contains references to more than 75,000 conferences in the Lending Division collection, is made available as a series of publications. These give access to a type of material which can be very difficult to trace in conventional bibliographic tools. The index is currently published monthly under the title Index of Conference Proceedings Received. (See figure 1.) Annual cumulations have been published for 1974 and subsequent years. 1976 Annual Cumulation indexes the 10,400 conferences received in 1976 . The ten-year cumulation, BLL Conference Index 1964-1973, contains details of 46,500 conferences under 27,500 keyword headings.

Current Serials Received, published in July 1977 , lists 48,750 serial titles re- ceived by the Lending Division on that date. The titles cover all subject fields and are divided into three sections: all titles excluding Cyrillic serials; Slavonic serial titles which are given in Roman alphabet; and cover-to-cover translations of Cyrillic serials.

The Lending Division's collection of cover-to-cover or selected translation journals is listed in Journals in Translation by alphabetical order of title, with a keyword index to subjects. (See figure 2.) The next edition of this publication will be published by the Lending Division jointly with the International Translations Centre (ITC) of Delft in The Netherlands and will probably be available early in 1978. It will also replace the ITC publication, Translations Journals.

"Collected Translations" is a series of translations grouped under broad subheads of translations prepared under the ad hoc scheme. To date, collections of translations of Archaeology, Ornithology, Creep Ecology, Marine Ecology, Reservoir Ecology, and Fish Farming have been published in the Lending Division.

The gratis publication, Translated Books Available from the BLLD, lists 120 books of which translations have been sponsored under the division's translating program and which are currently available from Boston Spa. Full bibliographical details about each book are given, together with a short description of the contents.

The Lending Division publishes its own journal, BLL Review, which appears quarterly. Initially a house journal, it gradually has become much more than this. It is now the only library journal specifically concerned with interlending, a topic of major and increasing importance. Many articles relate, of course, to interlending in the United Kingdom (the annual report of the Lending Division itself appears in the Review). More recently it has become 
INSERM - INTERNATIONAL DATA BASE

INSERM (continued)

May75 LES MYCOTOXINES- COMMUNICATIONS- COLLOQUE- INSERM- INSTITUT NATIONAL DE LA SANTE ET DE LA RECHERCHE MEDICALE

JUn 75 LIVER DISEASES IN CHILDREN- PROCEEDINGS OF A COLLOQUIUM- INSERM- INSTITUT NATIONAL DE LA SANTE ET DE LA RECHERCHE MEDICALE

JuI 75 SMOOTH MUSCLE PHARMACOLOGY AND PHYSIOLOGY- PROCEEDINGS OF A COLLOQUIUMINSERM- INSTITUT NATIONAL DE LA SANTE ET DE LA RECHERCHE MEDICALE

Sep 75 DISTRIBUTION DES ECHANGES GAZEUX PULMONAIRES- ACTES- COLLOQUE- INSERM- INSTITUT NATIONAL DE LA SANTE ET DE LA RECHERCHE MEDICALE

Mar 76 RESPIRATORY CENTRES AND AFFERENT SYSTEMS- PROCEEDINGS OF A COLLOQUIUM- INSERMINSTITUT NATIONAL DE LA SANTE ET DE LA RECHERCHE MEDICALE

Apr 76 COMMUNICATIONS- SEMINAIRE TECHNOLOGIQUE SUR LES NOUVELLES TECHNIQUES D'ETUDE DES PLAQUETTES SANGUINES- INSERM- INSTITUT NATIONAL DE LA SANTE ET DE LA RECHERCHE MEDICALE

May76 LES TECHNIQUES DE SEPARATION ET D'IDENTIFICATION DES LYMPHOCYTES HUMAINS- ACTESSEMINAIRE TECHNOLOGIQUE- INSERM- INSTITUT NATIONAL DE LA SANTE ET DE LA RECHERCHE MEDICALE

Jun 76 PRENATAL DIAGNOSIS- PROCEEDINGS OF A COLLOQUIUM- INSERM- INSTITUT NATIONAL DE LA SANTE ET DE LA RECHERCHE MEDICALE

INSTITUTIONS

Nov 74 INSTITUTIONS, POLICIES AND ECONOMIC PERFORMANCE- PAPERS PRESENTED AT A CARNEGIE-ROCHESTER CONFERENCE ON PUBLIC POLICY

Apr 75 INSTITUTIONS, POLICIES AND ECONOMIC PERFORMANCE- PAPERS PRESENTED AT A CARNEGIE-ROCHESTER CONFERENCE ON PUBLIC POLICY

INSTRUCTION

SeP 75 PROCEEDINGS OF THE SECTION ON INSTRUCTION OF THE 80TH ANNUAL MEETING OF THE

AMERICAN ACADEMY OF OPHTHALMOLOGY AND OTOLARYNGOLOGY

Apr 76 PAPERS AND REPORT OF THE CCAIT SPRING CONFERENCE ON INSTRUCTIONAL CHANGE STRATEGIES. COMMUNITY COLLEGE ASSOCIATION FOR INSTRUCTION AND TECHNOLOG

INSTRUCTIONAL CHANGE STRATEGIES
API 76 PAPERS AND REPORT OF THE CCAIT SPRING CONFERENCE ON INSTRUCTIONAL CHANGE STRATEGIES- COMMUNITY COLLEGE ASSOCIATION FOR INSTRUCTION AND TECHNOLOGY

INSTRUCTIONAL DEVELOPMENT

Mar 76 SUMMARY OF A WORKSHOP ON INSTRUCTIONAL DEVELOPMENT. ONTARIO UNIVERSITIES PROGRAM FOR INSTRUCTIONAL DEVELOPMENT

\section{NSTRUMENTATION}

JUI 76 INSTRUMENTATION FOR MECHANICAL ANALYSIS- COURSE NOTES FROM AN INTENSIVE SHORT COURSE- ENGINEERING SUMMER CONFERENCE- COLLEGE OF ENGINEERING, UNIVERSITY OF MICHIGAN

\section{SYSTEMS}

JUl 76 LOGICAL DESIGN FOR DIGITAL COMPUTER AND INSTRUMENTATION SYSTEMS- COURSE NOTES FROM AN INTENSIVE SHORT COURSE- ENGINEERING SUMMER CONFERENCE- COLLEGE OF ENGINEERING, UNIVERSITY OF MICHIGAN

\section{NTEUUGENCE} ENGIN

MaY 74 HUMAN DIVERSITY: ITS CAUSES AND SOCIAL SIGNIFICANCE- PROCEEDINGS OF A SEMINAR ON

Carnegie Mellon University 5020.86 VOL 41976 Pitts

Carnegie Mellon University

5020.86 VOL 41976 Pitts

Dallas Texas

8885.75 VOL 80 NO 3 MAY/JUN 1975

Greenville S C

3661.958F ED 122911

Greenville S C

3661.958F ED 122911

Wilfred Laurier University

Ontar

Ann Arbor Mich

9113.58 NO 761250

9113.58 NO 761849

Fig. 1

A Page from Index of Conference Proceedings Received 
64. DENKI KAGAKU KYOKAI/JOURNALELECTROCHEMICAL SOCIETY OF JAPAN

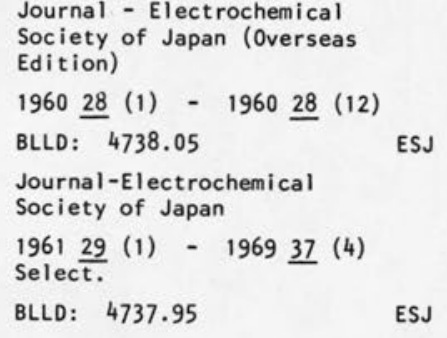

65. DENKI TSUSHIN GAKKAI ZASSHI/ JOURNAL-INSTITUTE OF ELECTRICAL COMMUNICATION ENGINEERS OF JAPAN

Electronics and Communications in Japan

1963 뜨 (1) - 1967 드 (12) BLLD: 3703.17

Continued as 67

* See diagram on page 12

66. DENSHI TSUSHIN GAKKAI RONBUNSHI/ TRANSACTIONS-INSTITUTE OF ELECTRONICS AND COMMUNICATION ENGININEERS OF JAPAN, SECTIONS A, B, C AND $D$.

Electronics and Communications in Japan (Scripta Electronica Japonica II)

$1968 \underline{51}$ (1) - $1969 \underline{52}$ (12)

BLLD: 3703.17

The translation then splits between two journals:

Electronics and Communications in Japan

$1970 \underline{53}$ (1) - mainly $A$ and $B$

BLLD: $3703.17 \quad$ SPC and

Systems, Computers, Control

(Scripta Electronica Japonica III)

$1970 \underline{53}$ (1) - $\operatorname{main} l y C$ and $D$

BLLD: 8589.325

* See diagram on page 12

67. DENSHI TSUSHIN GAKKAI ZASSHI/ JOURNAL-INSTITUTE OF ELECTRONICS AND COMMUNICATION ENGINEERS OF JAPAN

Electronics and Communications in Japan

$1967 \underline{50}$ (6) - $1967 \underline{50}$ (12)

BLLD: 3703.17

Formerly 65

* See diagram on page 12
68. DEREVOOBRABATYVAYUSHCHAYA

PROMYSHLENNOST'

Industrial Wood Processing

$1959 \underline{8}$ (7) - $1969 \underline{9}$ (12)

BLLD: 0412.17

TRDA

69. DERWENT BELGIAN PATENTS

REPORT ( $S$ )

1955 -

BLLD: 3555.35

DPL

70. DERWENT GERMAN PATENTS

REPORTS ( $S$ )

1959 - 1960 ?

BLLD: 3555.387

DPL

71. DERWENT JAPANESE PATENTS

REPORTS ( $S$ )

1962 -

BLLD: 3555.39

DPL

72. DERWENT NETHERLANDS PATENTS REPORTS (S)

1964 -

BLLD: 3555.55

DPL

\section{DERWENT RUSSIAN PATENTS}

REPORTS (S)

see 47

73. DEUTSCHE MEDIZINISCHE

WOCHENSCHRIFT

German Medical Journal

195580 - $1956 \underline{81}$ Select.

BLLD: 4162.13

German Medical Monthly

$1955 \underline{80}$ - $1970 \underline{95}$ Select.

BLLD: 4162.13

GTV

German Medicine

$1970 \underline{95}$ - $1973 \underline{98}$ Select.

BLLD: 4162.13

GTV

74. DIAGNOSTIKA PLAZMY

Recent Advances in Plasma

Diagnostics

1968 (2)

BLLD: 0420.723

75. DIAN ZI XUEBAO/TIEN TZU HSUEH PAO/ACTA ELECTRONICA SINICA

Electronics in Mainland China

1965 (1) - 1966 (2) Select.

BLLD: $\quad 3705.09$

SE

Fig. 2

A Page from Journals in Translation 
NEU ERWERBUNGEN DER BIBLIOTHEK - KOMMISSION DER

EUROPAISCHEN GEMEINSCHAFTEN

$(6077.212) \quad$ see 0578.883

NEW PUBLICATIONS - OFFICE FOR OFFICIAL PUBLICATIONS OF THE EUROPEAN COMMUNITIES

NEWSLETTER ON THE COMMON AGRICULTURAL POLICY

6108.61

NOMENCLATURE DES INDUSTRIES DES COMMUNAUTES EUROPEENNES N.I.C.E.

(6116.732) see GP

NOMENCLATURE DES PAYS COMMERCE EXTERIEUR-EUROSTAT

(6116.735) see 3481.893

NOTES EXPLICATIVES DU TARIF DOUANIER DES COMMUNATUES EUROPEENNES

6167.323

NOTE RAPIDE CARBON - EUROSTAT

$(6167.924) \quad$ see 5942.6

NOTES RAPIDES CHARBON - EUROSTAT

$(6167.925)$ see 5942.6

NOTE TECHNIQUE - COMMISSION DES COMMUNAUTES EUROPEENNES

(6168.62) see 8673.85

NOUVELLES - BUREAU EURISOTOP

6176.712

OBJECTIFS GENERAUX ACIER

6197.05

OFFICIAL INFORMATION - COMMISSION OF THE EUROPEAN COMMUNITIES

OFFICIAL JOURNAL - EUROPEAN COMMUNITIES - DEBATES OF EUROPEAN PARLIAMENT

OFFICIAL JOURNAL - EUROPEAN COMMUNITIES - INFORMATION AND NOTICES

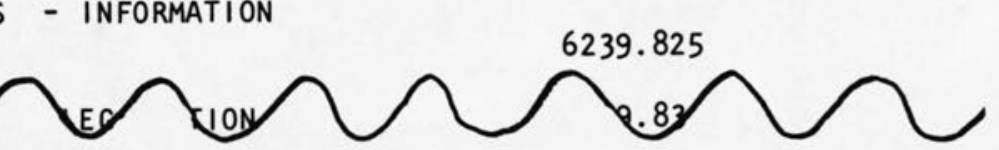

Fig. 3

A Page from Serial Publications of the European Communities and Its Institutions Held by the BLLD 
a vehicle for papers on international lending and on the interlending system of other countries, including, to date, the U.S.A. ${ }^{6}$ USSR, ${ }^{7}$ Scandinavia, ${ }^{8}$ and the Federal Republic of Germany. ${ }^{9}$ In 1978 the journal will change its title to become Interlending Review: Journal of the British Library Lending Division.

Several of the publications are available free of charge, mostly relating to the services of the library. The British Library Lending Division: A Brief Guide to its Services for Overseas Users is issued at intervals and presents a general outline of the division's services. It is also available in Italian and Spanish versions.

The Lending Division holds a comprehensive collection of EEC serials, which are listed in a free publication, Serial Publications of the European Communities and its Institutions Held by the BLLD. Titles are cross-referenced from French and German to the English title where they appear in the publications. Shelf marks are also given. (See figure 3.)

An IFLA Office for International Lending was established at Boston Spa in 1975. One of its activities is to collect basic information to aid libraries throughout the world in their international lending transactions. A Brief

\section{Guide to Centres of International} Lending and Photocopying is published by the office. It gives under each country the main characteristics of its international lending system, addresses to which requests should be sent, any restrictions imposed, and the length of the loan period.

The British Library Press and Public Relations Section produces a monthly publication, British Library News, which is distributed gratis to interested organizations at home and abroad. It is available free on request, as also is the British Library's Annual Report 1976/ 77.

All of the publications mentioned above are available from the British Library Lending Division, Boston Spa, Wetherby, West Yorkshire, United Kingdom LS23 7BQ. Order forms for publications will be sent on request.

\section{ConClusion}

As noted in the introduction, the activities described above are peripheral to the major interlending function of the British Library, but they add up to a substantial body of activities in their own right, not only aiding users of the library's services but contributing to bibliographic access to the professional literature and to the general dissemination of knowledge.

\section{REFERENCES}

1. M. B. Line, "The British Library Lending Division," in W. C. Saunders, ed., British Librarianship Today (London: Library Association, 1976), p.86-108.

2. M. B. Line, "Access to Resources through the British Library Lending Division," Aslib Proceedings 27:8-15 (1975).

3. "The British Library Lending Division in 1976/77," BLL Review 5:87-92 (1977).

4. A. G. Myatt, "Experiences in Educating the User at the NLL," in Educating the Library User: Proceedings of the 4th Triennial Meeting of IATUL, Loughborough, 1970 (Loughborough: International Association of Technological University Libraries, 1970), p.1-17.
5. British Library Review Committee on Education for Information Use, Final Report (Research and Development Report No. 5325HC; London: British Library, 1977).

6. S. McElderry, "Towards a National Information System in the United States," BLL Review 3:74-76 (1976).

7. N. G. Samokhina, "The System of Interlibrary Loan in the USSR," BLL Review 5: 13-17 (1977).

8. M. J. C. Terry, "Scandiaplan Report on Interlibrary Lending: A Summary," BLL Review 5:22-25 (1977).

9. J. Heydrich, "Interlending Policies and Plans in the Federal Republic of Germany," $B L L$ Review 4:47-50 (1976). 
Appendix 1

Translated Journals

Published on Behalf of the British Library Lending Division

Automatic Welding

Welding Institute

Abington Hall

Abington

Cambridge CB1 6AL

International Polymer Science and Technology

RAPRA

Shawbury

Shrewsbury

Shropshire SY4 4NR

Machines and Tooling

PERA

Melton Mowbray

Leicestershire LE13 OPB

Russian Chemical Reviews

The Chemical Society

Burlington House

London WC1B 5DT

Russian Engineering Journal

PERA

Melton Mowbray

Leicestershire LE13 OPB
Russian Journal of Inorganic Chemistry The Chemical Society

Burlington House

London WC1B 5DT

Russian Journal of Physical Chemistry

The Chemical Society

Burlington House

London WC1B 5DT

Russian Mathematical Surveys

Macmillan \& Co Ltd

4 Little Essex Street

London WC2R 3LF

Steel in the USSR

The Metals Society

1 Carlton House Terrace

London SW1Y 5DB

Thermal Engineering

Pergamon Press Ltd

Headington Hill Hall

Oxford OX3 OBW

Welding Production

Welding Institute

Abington Hall

Abington

Cambridge CB1 6AL 